\title{
"immunomodulators from natural products"
}

\author{
M. S. Hifnawy*, O. A. Rashwan*, Z. N. Said** \& M. A. Rabeh* \\ * Faculty of Pharmacy, Cairo University and \\ Faculty of Medicine, El-Azhar University, Cairo, Egypt.
}

\begin{abstract}
Immunostimulant plant extractives as well as its isolates constitute an alternative to conventional chemotherapy and prophylaxis of infections. In the present study eight plants (Ecballium elaterium, Luffa cylindrica, Cucurbita maxima, Agaricus bisporous, Pleurotus ostreatus, Oryza sativa (Rica bran), Tropaeolum majus and Echinacea purpurea) were primarily screened for specific and nonspecific immune responses. T. majus and E. elaterium were the most active, in addition to the well known immunostimulant E. purpurea. Tumor Necrosis factor-alfa (TNF- $\alpha$ ) and gamma Interferon (INF- $\gamma$ ) production were used as a measure of immunostimulatory activity.

"Cucurbitacin D" and "2-0- $\beta$-D-glucopyransoyl cucurbitacin I" of E.elaterium in addition to "5,3'-dihydroxy-7,4'-dimethoxy flavone" and 5,3'-dihydroxy-7,4' dimethoxy flavone -5-0-glucoside of T. majus were found to significantly stimulate the production of both TNF- $\alpha$ and INF- $\gamma$, while, "Androstan" and "4-acetyl-3,5-bis(methyl thio)-2-pyrrolin-5-Ol" of T. majus stimulated the production of INF- $\gamma$ only.
\end{abstract}

\section{INTRODUCTION}

Immunostimulation constitutes an attractive alternative to conventional chemotherapy and prophylaxis of infections. That is of prime importance when infectious diseases, persistent infections, chemotherapy-resistant bacteria and viral infections, have to be treated ${ }^{(1)}$. A second field of application is the prophylaxis of opportunistic infections of patients at risk due to lack of suitable medications such as viral infections. Further application is the therapy of malignant diseases where the tumor growth can be inhibited by stimulating specific components of the immune system, such as macrophages or T-killer cells. If chemically defined compounds were available that were capable of specifically stimulating immune system, it might be helpful in the therapy of autoimmune diseases such as rheumatoid arthritis, polyarthritis, chronic active hepatitis, myasthenia gravis, multiple sclerosis, psoriasis and others, immunostimulants having been used predominantly on the basis of empirical clinical observations ${ }^{(2)}$.

Tumor necrosis factor alpha $(\mathrm{TNF}-\alpha$, ) is an important cytokine involved in systemic inflammation 
and the acute phase response. It has a number of actions on various organ systems, generally together with interleukins 1 and 6: Stimulating of the hypothalamic-pituitary-adrenal axis by stimulating the release of corticotropin releasing hormone $(\mathrm{CRH})$, and stimulating the acute phase response of the liver leading to an increase in C-reactive protein and a number of other mediators.

Gamma-Interferon (IFN- is a typical lymphokine, being produced exclusively by activated natural killer cells and $\mathrm{T}$ lymphocytes. It is an activator of macrophages and thus increases their antitumor activities. If the macrophages are infected by intracellular parasites, it activates macrophages which in turn destroy the parasites. Suppression of intracellular parasites under the influence of IFN- takes place in the non-macrophage cells as well. IFNaffects differentiation of B-cells immune responses. In the late stages it increases the secretion of the immunoglobulins.

The aim of the present work is to demonstrate that in the future, apart from microbial preparations (Grampositive and Gram-negative bacteria), plant drugs and polyalcohol polymers isolated from fungi might play a role in enhancing either the nonspecific and/or specific immune response in albino mice model ${ }^{(3-5)}$. The total plant extractive that prove to be immunostimulant may be considered as prototype, the development of which may lead to novel promising immunostimulant compounds.

\section{MATERIALS \& METHODS}

\section{Plant extract:}

200 grams of plants under investigation (Pleurotus ostreatus, Agaricus bisporus, Rice bran, Tropaeolum majus, Echinacea purpurea, Ecballium elaterium, Luffa cylindrica, and Cucurbita maxima) were extracted by cold maceration in $70 \%$ alcohol (three extractions each with 2 liters) and evaporated to dryness under reduced pressure.

\section{Extract preparation for} immunostimulant bioassay:

Dried $70 \%$ alcohol extracts of plants under investigation were dissolved in Hank's solution in different concentrations (100, 500, 1000, 1500 and $2000 \mu \mathrm{g} \backslash \mathrm{ml})$. The extracts were sterilized by filtration through $0.2 \mu \mathrm{m}$ pore size filters and by addition of $10,000 \mu \mathrm{g}$ penicillin and $\quad 10,000 \quad \mu \mathrm{g} \quad$ streptomycin antibiotics.

3. Animals: Albino mice of either sex $(20-22$ g) were used for the following:-

Preparation of murine (mice) spleen cells:

Spleenocytes were prepared according to conventional procedures, from aseptically removed mouse spleens. The cells were washed three times in RPMI 1640 medium and resuspended in RPMI 1640 supplemented with $10 \%$ FCS, $2 \mathrm{mM}$ glutamine, $10 \mathrm{mM}$ HEPS, pencillin $100 \mathrm{U} / \mathrm{ml}$, streptomycin $100 \mu \mathrm{g} / \mathrm{ml}$ at a final concentration of $3 \times 10^{6}$ cells / $\mathrm{ml}$. Cell viability was evaluated by trypan blue exclusion test.

Lymphocyte cell culture:
Primary lymphoid cell culture
was performed by isolating


lymphocytes directly from mice spleens. The lymphocytes then were grown in a chemically defined growth medium RPMI 1640 supplemented with $10 \%$ FCS. Cell cultures were then used to study cytokines production involved in the activation, growth and differentiation of various cells involved in the immune response.

Macrophage culture:

Spleen cell suspension was incubated in flat bottomed microtiter plates at $37^{\circ} \mathrm{C}$ for 7 hours to allow the cells to adhere to the plates then the medium was removed and the adherent cells were washed three times with RPMI 1640. More than 95\% adherent cells were macrophage. The cells were cultured with different concentrations of each plant extract for 24 hours. The cells were further assayed for specific and nonspecific immune response.

A battery of assays was used to study the non- specific immune response of stimulated macrophages and lymphocytes, so certain functions of them were assayed including macrophage migration index, phagocytic index and viability percentage test in which the viable cells were counted using freshly filtered trypan blue stain and haemocytometer slide.

Macrophage migration index [Table (1)], Phagocytic index [Table (2)] and Viability percentage [Table (3)] showed the following results:

Table (1): Macrophage migration index of different plant extractives.

\begin{tabular}{|c|c|c|c|c|c|c|c|c|}
\hline Plant & Pleurotus & Agaricus & Rice bran & Tropaeolum & Echinacea & Ecballium & Luffa \\
- $\begin{array}{c}\text { Conc. } \\
(\boldsymbol{\mu g} / \mathbf{m l})\end{array}$ & ostreatus & bisporus & Oryza sativa & $\begin{array}{c}\text { Cucurbita } \\
\text { maxima }\end{array}$ \\
\hline $\mathbf{1 0 0}$ & 0.115 & 0.067 & 0.050 & 0.079 & 0.015 & 0.067 & 1.853 & 0.224 \\
\hline $\mathbf{5 0 0}$ & 0.208 & 0.187 & 0.042 & 0.079 & 0.018 & 0.045 & 1.336 & 0.208 \\
\hline $\mathbf{1 0 0 0}$ & 0.224 & 0.328 & 0.042 & 0.070 & 0.019 & 0.059 & 0.990 & 0.115 \\
\hline $\mathbf{1 5 0 0}$ & 0.093 & 0.406 & 0.035 & 0.059 & 0.034 & 0.059 & 0.531 & 0.052 \\
\hline $\mathbf{2 0 0 0}$ & 0.261 & 0.531 & 0.592 & 0.049 & 0.026 & 0.323 & 0.592 & 0.095 \\
\hline
\end{tabular}

Table (2): Phagocytic index of different plant extractives.

\begin{tabular}{|c|c|c|c|c|c|c|c|c|}
\hline Plant & \multirow[b]{2}{*}{$\begin{array}{c}\text { Pleurotus } \\
\text { ostreatus }\end{array}$} & \multirow[b]{2}{*}{$\begin{array}{l}\text { Agaricus } \\
\text { bisporus }\end{array}$} & \multirow{2}{*}{$\begin{array}{c}\text { Rice bran } \\
\text { Oryza } \\
\text { sativa }\end{array}$} & \multirow[b]{2}{*}{$\begin{array}{l}\text { Tropaeolum } \\
\text { majus }\end{array}$} & \multirow[b]{2}{*}{$\begin{array}{c}\text { Echinacea } \\
\text { purpurea }\end{array}$} & \multirow[b]{2}{*}{$\begin{array}{c}\text { Ecballium } \\
\text { elaterium }\end{array}$} & \multirow[b]{2}{*}{$\begin{array}{c}\text { Luffa } \\
\text { cylindrica }\end{array}$} & \multirow[b]{2}{*}{$\begin{array}{c}\text { Cucurbita } \\
\text { maxima }\end{array}$} \\
\hline $\begin{array}{c}\text { Conc. } \\
(\mu \mathrm{g} / \mathrm{ml})\end{array}$ & & & & & & & & \\
\hline 100 & 0.59 & 1.11 & 0.43 & 0.22 & 0.46 & 0.76 & 0.23 & 0.62 \\
\hline 500 & 0.96 & 0.48 & 0.62 & 0.28 & 0.36 & 0.58 & 0.60 & 0.30 \\
\hline 1000 & 1.65 & 0.84 & 0.63 & 0.37 & 0.56 & 1.06 & 0.95 & 0.46 \\
\hline 1500 & 1.57 & 1.39 & 0.48 & 0.37 & 0.92 & 1.09 & 0.89 & 0.47 \\
\hline 2000 & 0.98 & 1.30 & 0.37 & 0.77 & 1.38 & 1.12 & 0.71 & 1.04 \\
\hline
\end{tabular}


Table (3): Viability percentage of different plant extractives.

\begin{tabular}{|l|c|c|c|c|c|c|}
\hline Plant Conc. $(\mu \mathrm{g} / \mathbf{m l})$ & $\mathbf{1 0 0}$ & $\mathbf{5 0 0}$ & $\mathbf{1 0 0 0}$ & $\mathbf{1 5 0 0}$ & $\mathbf{2 0 0 0}$ & Control \\
\hline Pleurotus ostreatus & & & & & & \\
\hline Agaricus bisporus & $65 \%$ & $54 \%$ & $65 \%$ & $73 \%$ & $67 \%$ & $68 \%$ \\
\hline Oryza sativa (Rice bran) & $39 \%$ & $37 \%$ & $33 \%$ & $30 \%$ & $19 \%$ & $40 \%$ \\
\hline Tropaeolum majus & $48 \%$ & $50 \%$ & $57 \%$ & $74 \%$ & $70 \%$ & $52 \%$ \\
\hline Echinacea purpurea & $56 \%$ & $60 \%$ & $61 \%$ & $60 \%$ & $68 \%$ & $58 \%$ \\
\hline Ecballium elaterium & $54 \%$ & $63 \%$ & $57 \%$ & $62 \%$ & $68 \%$ & $54 \%$ \\
\hline Luffa cylindrica & $59 \%$ & $56 \%$ & $27 \%$ & $42 \%$ & $29 \%$ & $56 \%$ \\
\hline Cucurbita maxima & $44 \%$ & $28 \%$ & $48 \%$ & $63 \%$ & $64 \%$ & $56 \%$ \\
\hline
\end{tabular}

Results are average from 4 replicates

Non-specific immune response using "Macrophage migration index" showed the lowest Macrophage migration index with Echinacea purpurea followed by Ecballium elaterium and Tropaeolum majus.

The later two plant extractives showed appreciable non specific immunostimulant activity (low Macrophage migration index) comparable to the results displayed by Echinacea purpurea.

Rice bran extract showed low macrophage migration index at concentrations $(100-1500 \mu \mathrm{g} / \mathrm{ml})$ but not with conc. $2000 \mu \mathrm{g} / \mathrm{ml}$ ).

Regarding the non specific immune response using "phagocytic index", it was apparent that mushrooms (pleurotus ostreatus and Agaricus bisporous) in addition to Ecballium elaterium especially at high concentrations (1000-2000 $\mu \mathrm{g} / \mathrm{ml})$ had the highest immunostimulant effect.
In relation to "viability percentage", it was apparent, by comparison of each plant extract at different concentrations (100-2000 $\mu \mathrm{g} / \mathrm{ml}$ ) with its control, that both Echinacea purpurea and Ecballium elaterium at concentrations (500-2000 $\mu \mathrm{g} / \mathrm{ml}$ ) had higher viability $\%$ than that of control. Tropaeolum majus showed significantly high viability $\%$ at concentrations $(1000-2000 \mu \mathrm{g} / \mathrm{ml})$ while, Cucurbita maxima showed only higher viability $\%$ than its control at concentrations $1500-2000 \mu \mathrm{g} / \mathrm{ml}$.

The three experiments clearly demonstrated that Ecballium elaterium and Tropaeolum majus had considerable immunostimulant effect in addition to Echinacea purpurea (the well known marketed immunostimulant drug). This leads us to investigate the active constituents of Ecballium elaterium and Tropaeolum majus that possibly have such immunostimulant effect. 
Study of immunostimulant activity of different extractives of Ecballium elaterium \& Tropaeolum majus

One $\mathrm{kg}$ of each of Ecballium elaterium \& Tropaeolum majus was subjected to Successive extraction with different solvents of different polarities (petroleum ether, chloroform, ethyl acetate, alcohol $70 \%$, and water) using continuous extraction apparatus. The extraction with each solvent was continued until an aliquot of the last colorless percolate, left no residue when evaporated to dryness. After each extraction, the powder was taken out of the extractor and completely dried before using the next solvent. The solvent was removed completely from each extract, and the residue was dried to a constant weight.
The mean percentages for the different extracts of E. elaterium in petroleum ether, chloroform, ethyl acetate, alcohol $70 \%$, and water were $3.85,12.50,2.15,9.25$ and $13.10 \%$ respectively and they were $5.23,8.42$, $1.93,7.26$ and $12.60 \%$ respectively for T. majus.

The different extractives of $E$. elaterium \& T. majus were subjected to the following investigation.

Different extractives of Ecballium elaterium \& Tropaeolum majus were dissolved in Hank's solution in different concentrations $(100,500$, 1000, 1500 and $2000 \mu \mathrm{g} \backslash \mathrm{ml}$ ) and subjected to macrophage migration index, phagocytic index and viability percentage previously mentioned before. The results were presented in tables (4-6).

Table (4): Macrophage migration index of different extractives of Ecballium elaterium \& Tropaeolum majus.

\begin{tabular}{|c|c|c|c|c|c|c|c|c|c|c|}
\hline Plant & \multicolumn{5}{|c|}{ Ecballium elaterium } & \multicolumn{5}{|c|}{ Tropaeolum majus } \\
\hline $\begin{array}{l}\text { Conc. } \\
(\mu \mathrm{g} / \mathrm{ml})\end{array}$ & $\begin{array}{l}\text { Pet. } \\
\text { ether }\end{array}$ & $\mathrm{CHCl}_{3}$ & EtOAc & Alcohol & $\mathrm{H}_{2} \mathrm{O}$ & $\begin{array}{l}\text { Pet. } \\
\text { ether }\end{array}$ & $\mathrm{CHCl}_{3}$ & EtOAc & Alcohol & $\mathrm{H}_{2} \mathrm{O}$ \\
\hline 100 & 1.336 & 0.208 & 0.990 & 0.328 & 1.853 & 0.407 & 0.672 & 0.208 & 0.323 & 1.330 \\
\hline 500 & 0.990 & 0.115 & 0.406 & 0.226 & 0.592 & 0.225 & 0.453 & 0.224 & 0.188 & 0.990 \\
\hline 1000 & 0.592 & 0.093 & 0.225 & 0.208 & 0.328 & 0.114 & 0.187 & 0.093 & 0.094 & 0.491 \\
\hline 1500 & 0.531 & 0.067 & 0.328 & 0.095 & 0.337 & 0.042 & 0.092 & 0.087 & 0.115 & 0.323 \\
\hline 2000 & 0.406 & 0.067 & 0.180 & 0.052 & 0.208 & 0.042 & 0.045 & 0.026 & 0.041 & 0.209 \\
\hline
\end{tabular}


Table (5): Phagocytic index of different extractives of Ecballium elaterium \& Tropaeolum majus.

\begin{tabular}{|c|c|c|c|c|c|c|c|c|c|c|}
\hline Plant & \multicolumn{5}{|c|}{ Ecballium elaterium } & \multicolumn{5}{|c|}{ Tropaeolum majus } \\
\hline$(\mu \mathrm{g} / \mathrm{ml})$ & $\begin{array}{l}\text { Pet. } \\
\text { ether }\end{array}$ & $\mathrm{CHCl}_{3}$ & EtOAc & Alcohol & $\mathrm{H}_{2} \mathrm{O}$ & $\begin{array}{l}\text { Pet. } \\
\text { ether }\end{array}$ & $\mathrm{CHCl}_{3}$ & EtOAc & Alcohol & $\mathrm{H}_{2} \mathrm{O}$ \\
\hline 100 & 0.37 & 0.78 & 0.22 & 0.46 & 0.189 & 0.47 & 0.24 & 0.46 & 0.60 & 0.23 \\
\hline 500 & 0.48 & 0.99 & 0.27 & 0.58 & 0.56 & 0.58 & 0.52 & 0.38 & 0.89 & 0.38 \\
\hline 1000 & 0.79 & 0.98 & 0.36 & 0.92 & 0.48 & 0.79 & 0.82 & 0.56 & 0.71 & 0.46 \\
\hline 1500 & 0.93 & 1.57 & 0.48 & 0.97 & 0.58 & 0.93 & 0.96 & 0.92 & 0.95 & 0.53 \\
\hline 2000 & 0.89 & 1.38 & 0.65 & 1.04 & 0.78 & 1.44 & 1.08 & 1.38 & 1.04 & 0.64 \\
\hline
\end{tabular}

Table (6): Viability percentage of different extractives of Ecballium elaterium \& Tropaeolum majus.

\begin{tabular}{|c|c|c|c|c|c|c|c|c|c|c|}
\hline \multirow{2}{*}{$\begin{array}{l}\text { Conc. } \\
(\mu \mathrm{g} / \mathrm{ml})\end{array}$} & \multicolumn{5}{|c|}{ Ecballium elaterium } & \multicolumn{5}{|c|}{ Tropaeolum majus } \\
\hline & $\begin{array}{l}\text { Pet. } \\
\text { ether }\end{array}$ & $\mathrm{CHCl}_{3}$ & EtOAC & Alcohol & $\mathrm{H}_{2} \mathrm{O}$ & $\begin{array}{l}\text { Pet. } \\
\text { ether }\end{array}$ & $\mathrm{CHCl}_{3}$ & EtOAc & Alcohol & $\mathrm{H}_{2} \mathrm{O}$ \\
\hline 100 & $35 \%$ & $48 \%$ & $38 \%$ & $53 \%$ & $29 \%$ & $51 \%$ & $48 \%$ & $53 \%$ & $31 \%$ & $28 \%$ \\
\hline 500 & $39 \%$ & $57 \%$ & $39 \%$ & $62 \%$ & $41 \%$ & $56 \%$ & $51 \%$ & $51 \%$ & $48 \%$ & $39 \%$ \\
\hline 1000 & $40 \%$ & $68 \%$ & $48 \%$ & $68 \%$ & $30 \%$ & $62 \%$ & $58 \%$ & $59 \%$ & $61 \%$ & $53 \%$ \\
\hline 1500 & $44 \%$ & $70 \%$ & $53 \%$ & $73 \%$ & $39 \%$ & $68 \%$ & $63 \%$ & $64 \%$ & $69 \%$ & $54 \%$ \\
\hline 2000 & $59 \%$ & $74 \%$ & $49 \%$ & $69 \%$ & $44 \%$ & $73 \%$ & $70 \%$ & $74 \%$ & $72 \%$ & $58 \%$ \\
\hline Control & $48 \%$ & $48 \%$ & $48 \%$ & $48 \%$ & $48 \%$ & $48 \%$ & $48 \%$ & $48 \%$ & $48 \%$ & $48 \%$ \\
\hline
\end{tabular}

Results are average from 4 replicates

Non-specific immune response using "Macrophage migration index" showed the lowest Macrophage migration index with chloroform and alcohol extracts of Ecballium elaterium at concentrations $1500 \& 2000 \mu \mathrm{g} / \mathrm{ml}$ and pet. ether, chloroform, ethyl acetate and alcohol extracts of Tropaeolum majus nearly at the same concentrations.

They showed appreciable non specific immunostimulant activity
(Low Macrophage migration index) comparable to the results displayed by the control.

Regarding the non specific immune response using "phagocytic index", it was apparent that chloroform extract of E. elaterium at concentrations $500 \& 2000 \mu \mathrm{g} / \mathrm{ml}$ and in addition to alcohol extract at concentrations $1500 \& 2000 \mu \mathrm{g} / \mathrm{ml}$ together with pet.ether, chloroform, ethyl acetate and alcohol extracts 
Tropaeolum majus at concentrations $1500 \& 2000 \mu \mathrm{g} / \mathrm{ml}$ were the best as immunostimulants.

In determination of "viability percentage", it was apparent, by comparison of each plant extract at different concentrations (100-2000 $\mu \mathrm{g} / \mathrm{ml}$ ) with control, that both chloroform extract at concentrations $1500 \& 2000 \mu \mathrm{g} / \mathrm{ml}$ and alcohol extract at concentrations 500-2000 $\mu \mathrm{g} / \mathrm{ml}$ of $E$. elaterium had higher viability $\%$ than that of control. Pet. ether, chloroform, ethyl acetate and alcohol extracts of T. majus showed significantly high viability $\%$ at concentrations 1000-2000 $\mu \mathrm{g} / \mathrm{ml}$.

The three experiments suggested that chloroform and alcohol extracts of E. elaterium and pet.ether, chloroform, ethyl acetate and alcohol extracts of $T$. majus had considerable immunostimulant effect. This led us to investigate the active constituent of Ecballium elaterium and Tropaeolum majus that possibly to have such immunostimulant effect.

Investigation of the chloroform extract of Ecballium elaterium fruits (A. Rich.) F. Cucurbitaceae resulted in isolation of two compounds named " $\mathrm{EC}_{1}$ " and "EC $\mathrm{E}_{3}$ ".

Compounds "EC ${ }_{1}$ " and "EC $\mathrm{C}_{3}$ " gave positive test for cucurbitacins by spraying with vanillin/phosphoric acid reagent to give red and brown spots ${ }^{(6)}$. Its spectral data was identical to published data of "cucurbitacin E" and "cucurbitacin D" respectively ${ }^{(7-}$ 10).
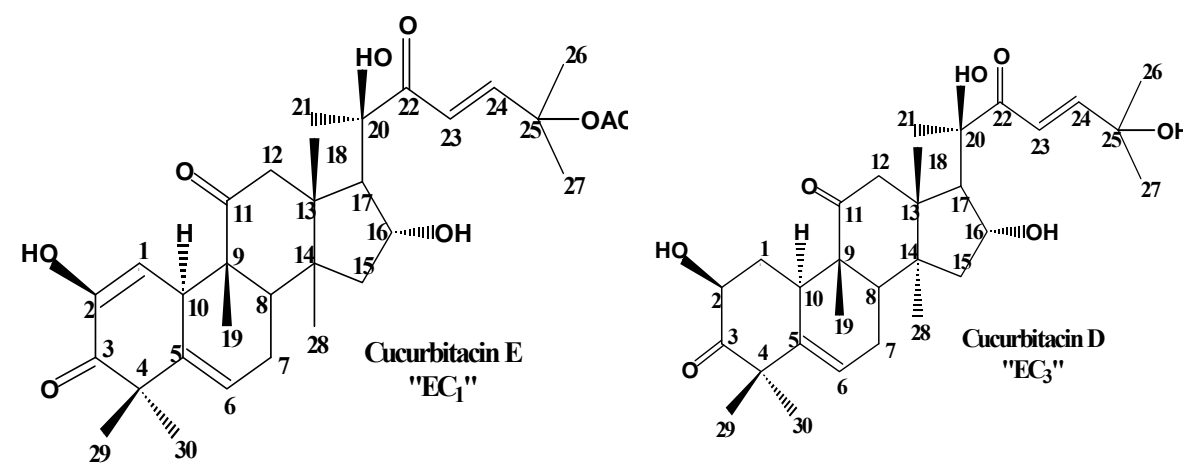

Investigation of the methanol extract of Ecballium elaterium fruits (A. Rich.) F. Cucurbitaceae resulted in isolation of one compound named "S $\mathbf{S}_{\mathbf{1}}$ ".

"2-O- $\beta-D$ glucopyranosyl-cucurbitacin I" 


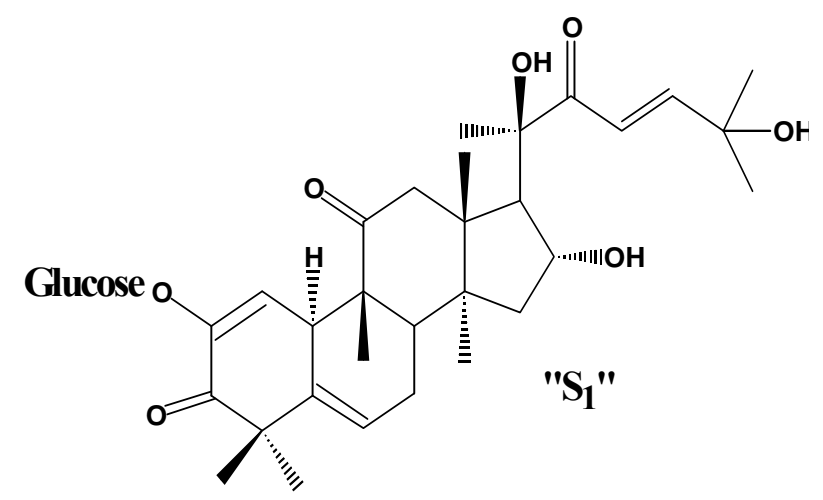

Investigation of the petroleum ether extract of Tropaeolum majus herb L. F. Tropaeolaceae resulted in isolation of two compounds named " $\mathbf{T}_{\mathbf{8}}$ " and " $\mathbf{T}_{\mathbf{1 0}}$ ".

Compound " $\mathbf{T}_{\mathbf{8}}$ " isolated from petroleum ether extract of Tropaeolum majus herb gave positive Leiberman-Burchard test for steroids and/or triterpenes. It was identified as "Androstane".

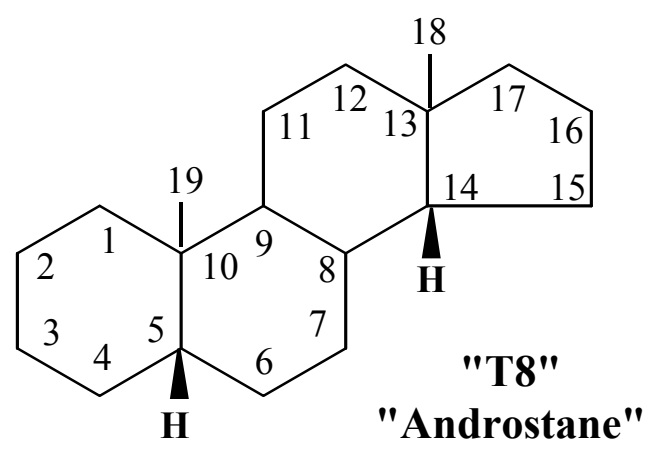

Compound " $\mathbf{T}_{\mathbf{1 0}}$ " responded negatively to Leiberman-Burchard test but gave faint orange Dragendorff's test for nitrogenous substances.

Compound " $\mathbf{T}_{\mathbf{1 0}}$ " was identified as a sulphur-compound "4-acetyl- 3, 5-bis(methyl thio)-2-pyrrolin-5-Ol" 


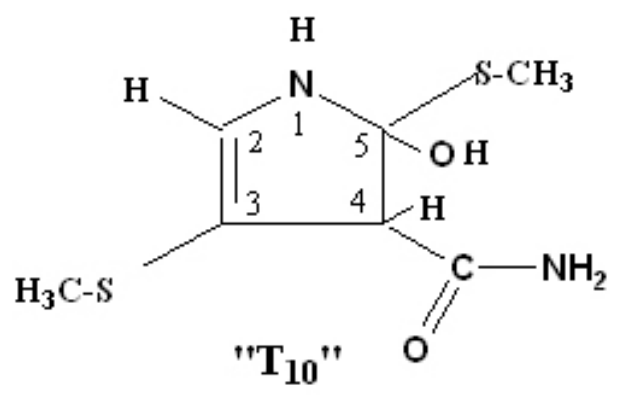

Investigation of the chloroform extract of Tropaeolum majus herb L. F. Tropaeolaceae resulted in isolation of one compound named " $\mathbf{T C}_{4}$ ".

Compound "TC 4 ", isolated from chloroform extract of Tropaeolum majus herb gave faint yellow color in visible light, yellowish blue in U.V., faint yellow in U.V./ $/ \mathrm{NH}_{3}$ and yellow color after spraying with $\mathrm{AlCl}_{3}$ spray reagent indicating the flavonoid nature. Compound "TC ${ }_{4}$ " was identified as "5, 3'-dihydoxy-7, 4'dimethoxy flavone" (13).<smiles>COc1cc(O)c2c(=O)cc(-c3ccc(OC)c(O)c3)oc2c1</smiles>

"5,3'-dihydroxy-7-4'-dimethoxy flavone ":

Investigation of flavonoids and other phenolic constituents of Tropaeolum majus herb L. F. Tropaeolaceae resulted in isolation of one compound named "TE $\mathbf{F}_{4}$ ".

Compound "TE $\mathbf{E}_{4}$ ", isolated from ethyl acetate extracts of Tropaeolum majus showed faint yellow color in visible light, yellowish blue in U.V. light \& in U.V./ $\mathrm{NH}_{3}$ and yellow color by spraying with $\mathrm{AlCl}_{3}$ spray reagent indicating the flavonoid nature. Compound "TE 4 " was identified as "5, 3'-dihydroxy-7, 4'-diemthoxy flavone-5-O-glucoside". 


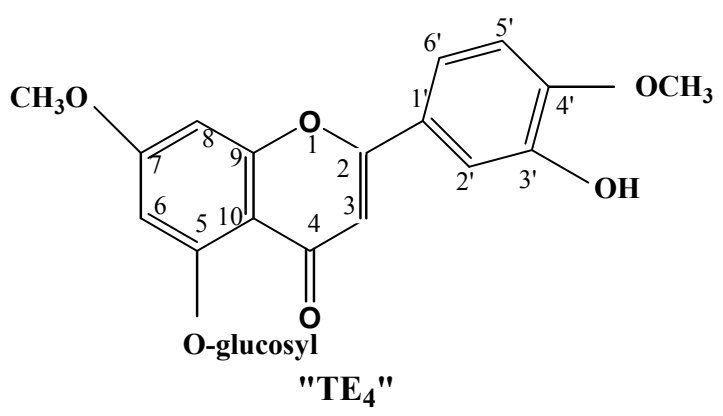

"5, 3'-dihydroxy-7, 4'-dimethoxy flavone-5-O-glucoside

Study of immunostimulant activity by the isolated compounds:

Tumor Necrosis factor-alpha (TNF- $\alpha$ ) and Gamma Interferon (INF$\gamma)$ production ('4), using CytElisa ${ }^{\mathrm{TM}}$ technique, were used as a measure of immunostimulant activity by seven compounds that were isolated in appreciable amounts $\left(\mathbf{E C}_{\mathbf{1}}, \mathbf{E C}_{\mathbf{3}} \boldsymbol{\&} \mathbf{S}_{\mathbf{1}}\right.$ from Ecballium elaterium and $\mathbf{T}_{\mathbf{8}}, \mathbf{T}_{\mathbf{1 0}}$,
$\mathbf{T C}_{\mathbf{4}} \boldsymbol{\&} \mathbf{T} \mathbf{T E}_{\mathbf{4}}$ from Tropaeolum majus) in comparison to marketed drug Echinacea purpurea. Three concentrations, $(0.5,50$ and 500 $\mu \mathrm{g} / \mathrm{ml}$ ), of isolated compounds were used and procedure was carried out according manufacturer procedure and results obtained were presented in table ( $\mathrm{v})$. 
Table (7): Concentrations of produced cytokines "TNF- $\alpha$ and INF- $\gamma$ " produced after treatment with isolated compounds:

\begin{tabular}{|c|c|c|c|c|c|c|c|}
\hline \multirow{3}{*}{$\begin{array}{l}\text { Isolated } \\
\text { compound }\end{array}$} & \multirow{3}{*}{$\begin{array}{l}\text { Conc. of } \\
\text { Isolated } \\
\text { compound } \\
(\mu \mathrm{g} / \mathrm{ml})\end{array}$} & \multicolumn{3}{|c|}{ Conc. of TNF. $\alpha(\mathrm{pg} / \mathrm{ml})$} & \multicolumn{3}{|c|}{ Conc. of INF- $\gamma(\mathrm{pg} / \mathrm{ml})$} \\
\hline & & \multicolumn{2}{|c|}{ Lymphocyte } & \multirow{2}{*}{$\begin{array}{l}\text { macrophage } \\
\text { After } 24 \text { hr. }\end{array}$} & \multirow{2}{*}{$\begin{array}{c}\text { After } 24 \\
\text { hr. }\end{array}$} & \multirow{2}{*}{$\begin{array}{c}\text { After } 48 \\
\text { hr. }\end{array}$} & \multirow{2}{*}{$\begin{array}{c}\text { After } 72 \\
\text { hr. }\end{array}$} \\
\hline & & $\begin{array}{l}\text { After } \\
24 \mathrm{hr} \text {. }\end{array}$ & $\begin{array}{l}\text { After } \\
48 \mathrm{hr} \text {. }\end{array}$ & & & & \\
\hline \multirow{3}{*}{$\mathrm{EC}_{1}$} & 0.5 & 5.95 & - & T.Y. & rV.q. & VA.YY & VT.YY \\
\hline & 50 & 11.99 & - & - & $V \leqslant .11$ & $Y \cdot . \wedge T$ & 9.04 \\
\hline & 500 & - & ५А.АV & - & $7 . .00$ & rV.Vq & $1 \leq V T$ \\
\hline \multirow{3}{*}{$\mathrm{EC}_{3}$} & 0.5 & $11 . \wedge \varepsilon$ & - & ro.rV & rVI.A. & $7 . .00$ & or.r. \\
\hline & 0. & tr. & rTV.07 & r.ov & TYV.11 & $1150 . .$. & $r \cdot .0$ \\
\hline & $0 .$. &. .19 & $T V . V \lambda$ & - & $r \leqslant .9$. & roN.7l & $\varepsilon \cdot Y_{T}$ \\
\hline \multirow{3}{*}{$\mathrm{S}_{1}$} & $\because 0$ & $V V . \wedge 0$ & 10.70 & tr.TV & $\wedge r . \wedge$ & $11 \leqslant .94$ & YA.IT \\
\hline & 0. & 0.1 & IAtrt & - & rY.IA & 97.11 & $Y \cdot .0$ \\
\hline & $0 .$. & - & - & r.AT & - & 9.04 & $V 7.9 Y$ \\
\hline \multirow{3}{*}{$\mathrm{T}_{8}$} & $\because 0$ & $r .90$ & - & $\varepsilon \cdot V \lambda$ & $|\pi| .$. & $r \cdot \varepsilon \cdot \ldots$ & ¿T!.Ar \\
\hline & 0. & $1 . \cdot V$ & - & $\varepsilon . \wedge r$ & $1 \cdots \wedge \varepsilon$ & $17 \varepsilon .1 \mathrm{~V}$ & $\varepsilon \cdot r .+\tau$ \\
\hline & $0 .$. & $\because 7$ & $\leqslant 9 . r \leqslant$ & $10 . \mathrm{VT}$ & $7 V . \vee A$ & $V \cdot . I Y$ & $r \leq q . r$ \\
\hline \multirow[t]{3}{*}{$\mathrm{T}_{10}$} & $\because 0$ & 1.19 & YI.TT & $1 \Sigma .4$ & $0 \wedge 0 . \leqslant 7$ & $\mid \wedge \wedge . .$. & $11 \varepsilon .$. \\
\hline & 0. & T.Y. & YV.ON & rA.r. & $11 \% \ldots$ & $r .9 . .$. & 197.1T \\
\hline & $0 .$. & r. 19 & - & $V . \leqslant 7$ & vo.r. & $r 70.07$ & rT.Vq \\
\hline \multirow{3}{*}{$\mathrm{TC}_{4}$} & .0 & $\Lambda . \leqslant 7$ & $\varepsilon 01.1 Y$ & r9.07 & TI.YY & $1 \leqslant Y . V$ & $|r V . Y|$ \\
\hline & 0. & A.rT & $9 . \leqslant 7$ & - & עr.ru & 9.04 & 19.19 \\
\hline & $0 \ldots$ & - & $7 . \wedge \Gamma$ & - & - & $0 \wedge . \wedge T$ & 111.1. \\
\hline \multirow{3}{*}{$\mathrm{TE}_{4}$} & .0 & $11 . r \varepsilon$ & $q . V \wedge$ & $\wedge 9 \wedge .7 r$ & $1 \leqslant 0 . \ldots$ & $I V Y, \ldots$ & $11 \ldots \ldots$ \\
\hline & 0. & Y.0 & ro. $\leqslant T$ & VVI.Y & $11 r \cdot .$. & INY... & $r \leqslant \Lambda . V r$ \\
\hline & $0 .$. & $1 \cdot . r \mid$ & $1 \cdots .91$ & $r \cdot .71$ & Tו. & OYT.YE & $9 \times 9.10$ \\
\hline \multirow{3}{*}{$\begin{array}{c}\text { Echinacea } \\
\text { extract }\end{array}$} & .0 & - & rA. Ir & 11.09 & $0 . \varepsilon .0$ & IV $\varepsilon .$. & $9 \leq .1$. \\
\hline & 0. & - & $1 . \cdot v$ & r.90 & $17 \varepsilon \varepsilon r$ & $1 V \varepsilon .17$ & $0 \wedge . \wedge T$ \\
\hline & $0 \ldots$ & $7 . V 1$ & $\varepsilon . \wedge$ & - & $Y \cdot . \wedge T$ & - & - \\
\hline
\end{tabular}

\section{DISCUSSION}

Evaluation of isolated compounds from Tropaeolum majus and Ecballium elaterium, relative to the reference plant Echinacea purpurea, for specific immune response to produce cytokines (TNF- $\alpha$ and INF- $\gamma$ ) clearly demonstrated good inductive effect for production of TNF- $\alpha$ by lymphocytes displayed by compounds "EC $\mathbf{C}_{3}$ " $(50 \mu \mathrm{g} / \mathrm{ml})$, "S $\mathbf{S}_{1}$ (0.5 $\left.\mu \mathrm{g} / \mathrm{ml}\right)$, "TC 4 " $(0.5 \mu \mathrm{g} / \mathrm{ml})$ and "TE 4 " (0.5 and
$500 \mu \mathrm{g} / \mathrm{ml}$ ) after $48 \mathrm{hrs}$ producing 367.36, 85.65, 182.37, 458.12, 90.78, and $100.91 \mathrm{Pg} / \mathrm{ml}$ respectively while, only compound "TE 4 " displayed good inductive effect for production of TNF- $\alpha$ by macrophages producing 898.62 and $776.26 \mathrm{Pg} / \mathrm{ml}$ at concentrations 0.5 and $50 \mu \mathrm{g} / \mathrm{ml}$ of compound " $\mathbf{T E}_{4}$ " respectively.

Regarding the production of INF$\gamma$ after treatment of macrophages for 24, 48 and 72 hours it was apparent that compounds "EC $\mathbf{C}_{3}$ " and " $\mathbf{S}_{\mathbf{1}}$ " displayed good inductive effect after 
24 and 48 but not after 72 hours while, compounds" $\mathrm{T}_{8} ", " \mathrm{~T}_{10} "$ and "TE 4 " were powerful inductive for the production of INF- $\gamma$ after 24,48 and 72 hours resulting in production of high amount of such cytokine reached $2090.00 \quad \mathrm{Pg} / \mathrm{ml}$ with compound " $\mathbf{T}_{\mathbf{1 0}}$ ".

It was clear that the non acetylated form of the cucurbitacin compound " $\mathbf{E C}_{\mathbf{3}}$ " was more active that the acetylated form "EC $\mathbf{C}_{1}$ ".

Compound " $\mathbf{T}_{\mathbf{8}}$ " which is a steroidal compound displayed a powerful effect for production of INF$\gamma$. Also compound " $\mathbf{T}_{\mathbf{1 0}}$ " which is a sulfur compound showed the highest level of INF- $\gamma \quad(2090.00 \mathrm{pg} / \mathrm{ml})$ production suggesting the possible effect of natural sulfur compounds as immunostimulant drugs.

In addition compound " $\mathbf{T E}_{4}$ " as a flavonoid glycoside displayed higher immunostimlant effects than its flavonoid aglycone " $\mathbf{T C}_{4}$ " suggesting that the sugar moiety of the glycoside might play an important rule in cytokine production.

As a conclusion, Cucurbitacin D "EC $\mathbf{C}_{3}$ " and 2-0- $\beta$-D-glucopyransoyl cucurbitacin I " $\mathbf{S}_{\mathbf{1}}$ " of E.elaterium in addition to 5,3'-dihydroxy-7,4'dimethoxy flavone"TC ${ }_{4}$ " and 5,3'dihydroxy-7,4' dimethoxy flavone - 50 - glucoside "TE 4 " of T. majus were found to significantly stimulate the production of both TNF- $\alpha$ and INF- $\gamma$, while, Androstan "T. $\mathbf{T}_{\mathbf{8}}$ " and 4-acetyl3,5-bis-(methyl thio)-2-pyrrolin-5-O1 " $\mathbf{T}_{\mathbf{1 0}}$ " of $T$. majus stimulated the production of INF- $\gamma$ only.

Cucurbitacins, steroidal compounds, sulfur compounds and flavonoids might play an important rule in immunostimulation.

\section{RECOMMENDATIONS}

We need to pay more attention to our Egyptian flora as it presents more convenient and in some instances superior to the already established and marketed drug formulations.

Promising new compounds that were isolated from Ecballium elaterium and Tropaeolum majus extractives should be subjected to extensive clinical and pharmacokinetic studies to support their presentation in drug market.

\section{REFERENCES}

1. Mayr, A.; Raetting, H.; Stickl, H.; and Alexander, M. (1979): "Immunstimulation: An alternative to conventional chemotherapy and prophylaxis of infections" "Fortschr. Med." 97: 1205.

2. Wagner, H.; Hikino, H.; and Fransworth, N. (1985): "Immunstimulatory drugs of fungi and higher plants" edited by Academic press, London, Orlando, San Diego, Toronto, Montréal , Sydney and Tokyo, Chapter 4: p. 114-115.

3. Peakman, M. and Vergani, D. (1997): "Basic and clinical immunology" chapter 1 p.1-4 edited by Churchill Livingstone, New York, Edinburgh, London, Madrid, Melbourne, San Francisco and Tokyo.

4. Afrozul, H.; Mohammad, A.; Peter, I.; Khalid, S.; Kirtikant, V.; and Sultan, T. (1995): "Nigella sativa: effect on human 
lymphocyte and

polymorphonuclear leucocytes phagocytic activity" Immunopharmacology 30: 147155.

5. Labadie, R.; Van der Nat, J.; Simons, J.; Kroes, B.; Van den Berg, J.; Hart, L.; Van der Sluis, W.; Abeyysekera, A.; Bamunuarachchi, A.; and De Silva, K. (1989): “An ethnooharmacognostic approach to the search for immunomodulators of plant origin”. Planta Medica, 55: 339348.

6. El-Zalabani, S. (1977): “A pharmacognostical study of certain plants belonging to family cucurbitaceae" PH. D. Thesis, Faculty of Pharmacy, Cairo University, Egypt.

7. Magd, M. (1986): "Constituents of Acanthosicyos forrius roots", PH.D. Thesis, London University.

8. Achenbach, H.; Horn, K.; Dominguez, X.; Rombold, C.; and Lopez, E. (1993): "Cucurbitanes and Cucurbitanetype glycosides from Ibervillae sonorae" Phytochemistry 33: (2), 437.

9. Achenbach, H.; Waibel, R.; Hafter-Bubl, U.; and Constrenla, T. (1993):
"Constituents of Fevillea cordifolia: New norcucurbitacin and cucurbitacin glycosides" $J$. Nat. Prod. 56: 1506.

10. Huang, Y.; Bruyne, T.; Apers, S.; Yuliang, M.; Claeys, M.; Berghe, D.; Pielters, L.; and Vlietinck, A. (1998): "Complement-inhibiting cucurbitacin glycosides from Picria fel-terrae" J. Nat. Prod., 61:(6), 757.

11. Hatam, N.; Whiting, D.; and Yousif, N. (1989): "Cucurbitacin glycosides from Citrullus colocynthis." Phytochemistry 28: (4), 1265-1271.

12. Hostettman, K.; and Marston, A. (1995): "Chemistry and pharmacology of natural products-Saponins." $1^{\text {st }}$ edition by Cambridge University Press, p.11-20.

13. Yamaguchi, K. (1970): "Spectral data of natural products." Elsevier publishing company Amsterdam, London, New York, vol. I: P.183211.

14. Kayser, O.; Kolodziej, H. and Kidderlen, A. (2001): "Immunomodulatory principles of Pelargonium sidoides" Phytotherapy Research 15: 122126. 


\section{مُمَدِلات المناعة من مصادر طبيعية}

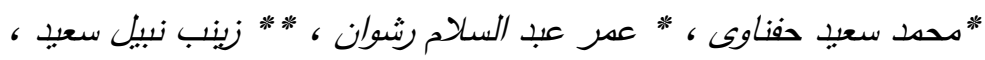

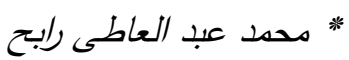

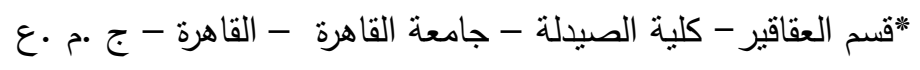

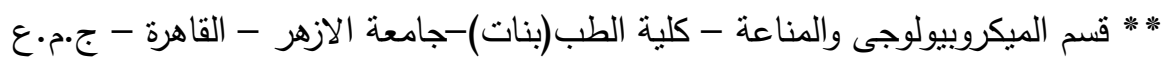

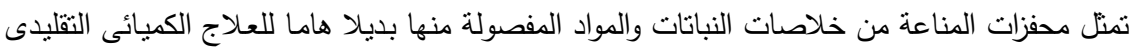

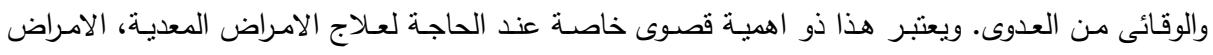

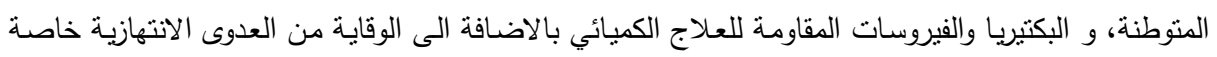

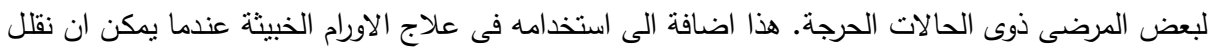

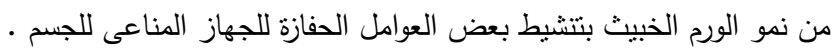

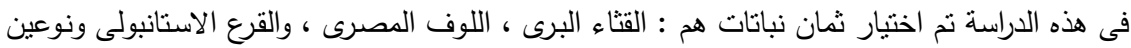

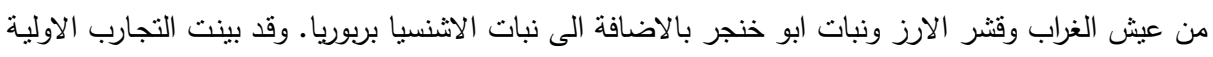

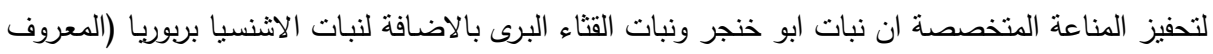

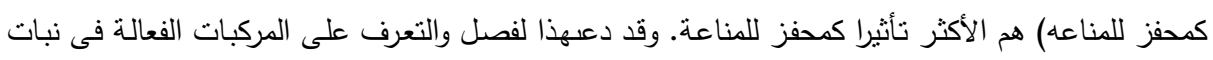

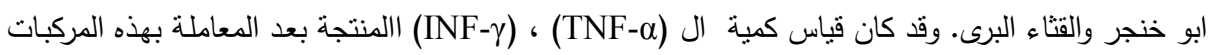

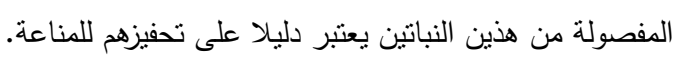

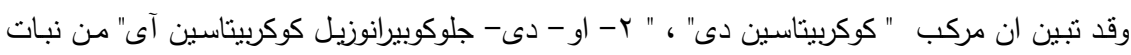

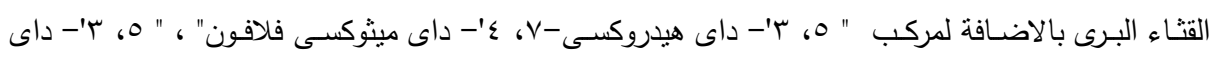

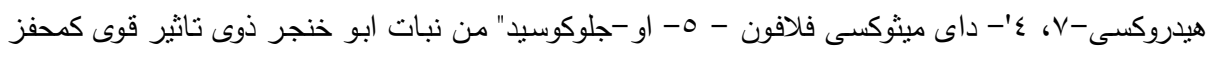

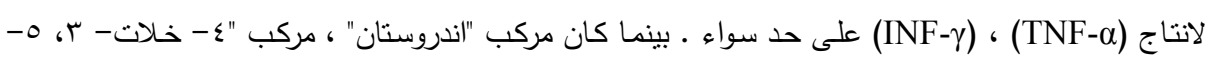

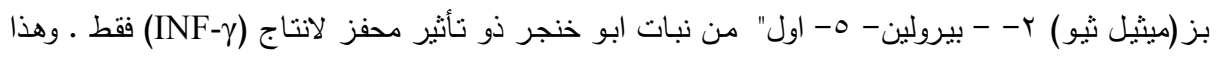
يبيين تأثير هذه المركبات كمحفز للمناعة. 